\title{
Acrylamide alters neurotransmitter induced calcium responses in murine ESC-derived and primary neurons
}

\author{
Julia Sisnaiske ${ }^{\mathrm{a}, *}$, Vanessa Hausherr ${ }^{\mathrm{a}}$, Anne K. Krug ${ }^{\mathrm{b}}$, Bastian Zimmer ${ }^{\mathrm{b}, \mathrm{c}, \mathrm{d}}$, \\ Jan G. Hengstler ${ }^{\mathrm{a}}$, Marcel Leist ${ }^{\mathrm{b}}$, Christoph van Thriel $^{\mathrm{a}}$ \\ a IfADo - Leibniz Research Center for Working Environment and Human Factors, Dortmund, Germany \\ ${ }^{\mathrm{b}}$ University of Konstanz, Doerenkamp-Zbinden Chair for In Vitro Toxicology and Biomedicine, Konstanz, Germany \\ ${ }^{\mathrm{c}}$ Center for Stem Cell Biology, Sloan-Kettering Institute for Cancer Research, New York City, USA \\ ${ }^{\mathrm{d}}$ Developmental Biology Program, Sloan-Kettering Institute for Cancer Research, New York City, USA
}

Keywords:

Acrylamide

Neurotoxicity testing

Stem cell

3R

Neuronal function

\begin{abstract}
A B S T R A C T
Stem cell derived specialized cell types are of interest as an alternative cell system to identify and research neurotoxic effects and modes of action. Developmental toxicity may be studied during differentiation, while organ specific toxicity may be assessed in fully functional cells, such as neurons. In this study we tested if fully differentiated neurons derived from murine embryonic stem cells (ESCN) could be used to investigate the effects of the well characterized neurotoxic model compound acrylamide (ACR) and if ESCN behave similar to murine primary cortical neurons ( $\mathrm{pCN}$ ) from 16 days old embryos. We characterized the differentiation process of cryopreserved ESC derived neural precursor cells (NPC) differentiating to ESCN. During the differentiation process (days 1120 ) a strong increase in calcium responses to glutamate, acetylcholine and GABA were observed. Moreover, neuron specific marker proteins, $\beta$ III tubulin, MAP2, Tau, Rbfox3 and synaptophysin showed similar patterns to pCN. In ESCN and pCN the neuronal structure, e.g. neurites, was not affected by low concentrations of ACR [0.5 $1.6 \mathrm{mM}$ ]. However, $24 \mathrm{~h}$ incubation periods with $0.51 .6 \mathrm{mM}$ ACR led to a reduction of acetylcholine and glutamate induced calcium responses. In conclusion, we show that non cytotoxic concentrations of ACR alter neurotransmission in ESCN as well as pCN.
\end{abstract}

\section{Introduction}

Recent papers in stem cell biotechnology (Brustle, 2013; Lancaster et al., 2013) have shown that properties of some relatively complex human tissues can be investigated in in vitro models. For example, cerebral organoids derived from human pluripotent stem cells have been developed to investigate microcephaly, a neurode velopmental disorder (Lancaster et al., 2013). Cellular test systems

Abbreviations: ACh, acetylcholine; ACR, acrylamide; $\left[\mathrm{Ca}^{2+}\right]_{\mathrm{i}}$, intracellular calcium concentration; $\mathrm{Cl}$, confidence interval; DoD, day of differentiation; $\mathrm{ESCN}$, embryonic stem cell derived neuron (NPC at DoD20); Glu, glutamate; MAP, microtubule associated protein; Rbfox3, RNA binding protein fox-1 homolog = NeuN; NPC, neural precursor cell (DoD7-19); NT, neurotransmitter; pCN, primary cortical neuron; Syp, synaptophysin; Tubb3, neuronal $\beta$-III-tubulin.

* Corresponding author. IfADo-Leibniz Research Center for Working Environment and Human Factors, Ardeystr. 67, 44139 Dortmund, Germany.

Tel.: +490231 1084414

E-mail addresses: julia.sisnaiske@rub.de, sisnaiske@ifado.de (J. Sisnaiske). have been established (Krug et al., 2013a,b) in order to identify molecular pathways underlying toxic events (Collins et al., 2008; Leist et al., 2008b) in different target organs (e.g. liver, brain, etc.). With in vivo testing an exceedingly high number of animals would be needed to test all major chemicals for safety. Therefore, the new NRC strategy suggests to rather identify pathways of toxicity and mechanisms of actions of toxicants in vitro and then to extrapolate the data to the human situation. For instance, many toxic effects relevant for the action of chemicals on the developing brain can be observed and quantified in in vitro systems. This can be achieved using stem cells differentiating towards neuronal cells (van Thriel et al., 2012; Kadereit et al., 2012). A specific advantage of these stem cell derived in vitro systems is, that large cell batches can be distributed between different research groups and reduce inter laboratory variability. These are also good conditions for high throughput methods.

The nervous system has a special relevance in toxicity testing (van Thriel et al., 2012). Neurons are particularly susceptible to toxins due to their constitution and architecture. They have long 
processes axons and dendrites, collectively termed neurites which innervate the whole body and possess numerous branches. Moreover, they transmit information as electrical signals that are transformed into chemical signals at the synapses. With this unique connectivity they form huge networks characterized by activity dependent dynamics as well as inhibitory and excitatory pathways (e.g. Bear et al., 2008; Kandel et al., 2000). All these features render the neuronal network a complex system, vulnerable to toxic events. Accordingly, neurotoxicity testing is an important aspect for human risk assessment (Rohlman et al., 2008).

In addition to their use in clinical and basic research, stem cell derived neurons are a good alternative system to assess neurotoxic effects and modes of action (Klemm and Schrattenholz, 2004). Due to their potential to differentiate, embryonic stem cells (ESC) provide unlimited access to all cell types of the body, and they offer the possibility to observe toxic effects during development (Leist et al., 2008a). Different cell systems are already used to investigate the differentiation and maturation of neurons, and possible factors disturbing these processes, for example neurotoxins (e.g. Fritsche et al., 2005; Gassmann et al., 2010; Huang and Schneider, 2004; Tamm et al., 2006; Tateno et al., 2004; Zimmer et al., 2011, 2012).Up to now, these cell systems have hardly been used to analyze toxic effects on fully differentiated neurons, yet (Visan et al., 2012; Zeng et al., 2006); especially not, when toxins affect neuronal function. Such effects have been demonstrated using electrophysiological methods in cultures of primary neurons from rodents (Defranchi et al., 2011; Stett et al., 2003; van Vliet et al., 2007). Due to the extensive use of functional primary neuronal cells from rodent species in neurotoxicology (Howard et al., 2005; Schmuck and Schluter, 1996) we therefore wanted to characterize fully differen tiated mouse embryonic stem cell derived neurons (ESCN) of the CGR8 line and assess their suitability for functional neurotoxicity testing in comparison to murine primary cortical neurons ( $\mathrm{pCN}$ ). For this comparison acrylamide (ACR) was used as a positive control compound. ACR is a water soluble monomer, which can be found in food, tobacco smoke (Tareke et al., 2000) and is widely used occupationally, for example in the production of plastics and cosmetics, in wastewater treatment or as a soil conditioner (Friedman, 2003). ACR is a neurotoxin and leads to peripheral and central neuropathies and the degeneration of neurites (Spencer and Schaumburg, 1975; Suzuki and Pfaff, 1973). While many studies have shown an impairment of the neuronal structure, there is also some evidence that ACR may disturb the neuronal function, too: In 1996 Crofton et al. observed an impaired motor activity in rats already $2 \mathrm{~h}$ after ACR exposure without any neuropathological damage. Tunnel workers, exposed to ACR, showed disturbed neuronal function, but no effects on structural integrity of the nervous system (Goffeng et al., 2008). Recently, the affinity of ACR to cysteine thiolate groups located in active sites of synaptic compartments has been discussed as molecular mechanism of ACR neurotoxicity (LoPachin and Gavin, 2012). These findings and mechanistic considerations of Goffeng, Crofton and colleagues led us to the hypothesis that an acute exposure to low concentrations of ACR rather impairs neuronal function than neuronal structure. To test this hypothesis we analyzed changes of intracellular calcium in response to different neurotransmitters (NT) utilizing both cell types, ESCN and pCN. Here, we report that short term ACR exposure indeed reduces mean response amplitudes of different NT. Similar results were obtained for ESCN and $\mathrm{pCN}$.

\section{Materials and methods}

\subsection{Dissection and culture of primary cortical neurons}

All experiments were conducted in accordance with national laws for the use of animals in research and approved by the local ethical committee. Isolation of $\mathrm{pCN}$ from $\mathrm{C} 57 \mathrm{BL} / 6 \mathrm{~N}$ mice at embryonic day 16 was conducted as described in Dinh et al. (2013; see suppl. material). After removing the meninges, cortices were minced and transferred to fresh HBSS buffer with $0.125 \%$ trypsin (PANBiotech) and incubated for $10 \mathrm{~min}$ at $37^{\circ} \mathrm{C}$. After adding $0.25 \mathrm{mg} / \mathrm{ml}$ soybean trypsin inhibitor (Life Technologies) and 0.01\% DNase (Sigma Aldrich), cortices were triturated with three fire polished Pasteur pipettes 1520 times with decreasing tip diameters. Subsequently, cells were centrifuged ( $200 \mathrm{~g}$ for $5 \mathrm{~min}$ ) and the cell pellet was resuspended in Neurobasal medium (Life Technologies) containing $1 \times$ B 27 serum free supplement (Life Technologies), $0.1 \%$ Gentamycin (PANBiotech) and $0.5 \mathrm{mM}$ stabi lized Glutamine (PANBiotech). pCN were plated at a density of 60,000 cells $/ \mathrm{cm}^{2}$ on $0.01 \%$ poly L lysine (Sigma) coated surfaces and cultivated at $37{ }^{\circ} \mathrm{C}$ and $5 \% \mathrm{CO}_{2}$. Half of the medium was changed every fourth day. For toxicity tests $\mathrm{pCN}$ were analyzed after 4 days in vitro (DIV 4). On that day pCN were still able to respond to GABA in calcium imaging experiments and were more comparable to ESCN.

\subsection{Culture and differentiation of murine CGR8 stem cells}

For culture of CGR8 cells only plastic ware with Nunclon Delta (Nunc) surface or $\mathrm{HCl}$ etched glass was used for enhanced cell attachment. Incubation of glass with $\mathrm{HCl}$ removed any organic residues for a better binding of poly L lysine or poly L ornithin. Undifferentiated pluripotent stem cells of the murine ESC line CGR8 were routinely cultured in Glasgow's modified Eagles medium (GMEM), supplemented with $10 \%$ heat inactivated fetal bovine serum (FBS; PAA), $2 \mathrm{mM}$ stabilized glutamine, $100 \mathrm{mM}$ nonessential amino acids, $50 \mathrm{mM} \beta$ mercaptoethanol (Life Tech nologies), $2 \mathrm{mM}$ sodium pyruvate and $1,000 \mathrm{U} / \mathrm{ml}$ leukemia inhibitory factor (Chemicon) on $0.1 \%$ gelatine at $37{ }^{\circ} \mathrm{C}$ and $5 \%$ $\mathrm{CO}_{2}$ as described in Zimmer et al. (2011). To start the differentia tion process towards neural linage, the medium was changed to N2/B 27 medium (DMEM/F 12:Neurobasal 1:1, 0.5 $\times$ N2, 0.5 $\times$ B 27 (Life Technologies), $0.05 \mathrm{mg} / \mathrm{ml} \mathrm{BSA} \mathrm{(Calbiochem),} 2 \mathrm{mM}$ stabilized glutamine, $0.75 \mu \mathrm{l} / \mathrm{ml}$ Insulin $(9.510 .5 \mathrm{mg} / \mathrm{ml}$, Sig ma Aldrich), $0.1 \mathrm{mM} \beta$ mercaptoethanol (Ying and Smith, 2003), and cells were re plated on gelatine coated surfaces at $10^{4}$ cells/ $\mathrm{cm}^{2}$. After seven days of differentiation (DoD7) cells were harvested and frozen in liquid nitrogen for shipment to IfADo. For further differentiation, cells were quickly thawed in a $37^{\circ} \mathrm{C}$ water bath, transferred into fresh N2/B 27 medium, and after centrifugation at $300 \mathrm{~g}$ for $3 \mathrm{~min}$, plated on poly L ornithin/ laminin $(10 \mu \mathrm{g} / \mathrm{ml}$ each, Sigma Aldrich) coated surfaces at 15,000 cells $/ \mathrm{cm}^{2}$. First exchange of medium was performed after 3 days and subsequently every other day. In the following, we use the abbreviation NPC (neural precursor cells) for differentiating cells from DoD7 until DoD19 and ESCN for fully differentiated embryonic stem cell derived neurons at DoD20. After this day there was no further change detectable with respect to the protein and mRNA analysis of neuronal markers of Zimmer et al. (2011).

\subsection{Immunofluorescence}

For immunocytochemistry NPC and $\mathrm{pCN}$ were plated on poly $\mathrm{L}$ ornithin/laminin or poly L lysine coated $14 \mathrm{~mm}, \mathrm{HCl}$ etched glass coverslips, respectively. Cells were fixed with $4 \%$ paraformalde hyde (Roti Histofix, Carl Roth) for 15 min followed by permeabi lization of cell membranes for 10 min with $0.1 \%$ Triton X 100 in PBS (phosphate buffered saline). Nonspecific binding sites were blocked with 5\% normal donkey serum (dianova) in PBS for $1 \mathrm{~h}$. Fixed cells were incubated with primary antibodies for $2 \mathrm{~h}$ at room temperature: polyclonal rabbit anti $\beta$ III tubulin (Cov ance, 1:2,000), monoclonal mouse anti nestin (Millipore, 1:100), 
monoclonal mouse anti Rbfox3 (Millipore, 1:200), monoclonal mouse anti synaptophysin (Santa Cruz, 1:100), polyclonal rabbit anti Tau (abcam, 1:200) and polyclonal chicken anti MAP2 (abcam, 1:200). After the following incubation with fluoro chrome labeled secondary antibodies for $30 \mathrm{~min}$ (donkey anti chicken IgY cy3, donkey anti rabbit IgGdylight 488, donkey anti mouse IgG cy $3,1: 500$, dianova), nuclei were stained with DAPI ( $4^{\prime}$, 6 diamidino 2 phenylindole, Life Technologies) for $30 \mathrm{~min}$. Cover slips were mounted to microscopic slides with FluorPreserve ${ }^{\mathrm{TM}}$ Reagent (Calbiochem). Immunostainings were analyzed with a Leica DMI 6000 B microscope, a monochrome CCD camera DFC 360 FX and Leica LAS AF 600 Software with identical settings for both cell types.

\subsection{Cell viability assay}

To assess cytotoxic concentrations of ACR cells were grown on 24 well plastic plates and treated with different concentrations of the toxin. After $24 \mathrm{~h}$ cell viability was determined using the CellTiter Blue ${ }^{\circledR}$ Cell Viability Assay (Promega) according to the manual: $2 \mathrm{~h}$ (ESCN) or $4 \mathrm{~h}$ ( $\mathrm{pCN}$ ) before the end of exposure, cells were incubated along with $1 / 5$ of the CellTiter Blue ${ }^{\circledR}$ compound at $37{ }^{\circ} \mathrm{C}$. Subsequently, $100 \mu \mathrm{l}$ media of each well were transferred to a black 96 well plate to measure fluorescence. Fluorometric analysis involved excitation at $540 \mathrm{~nm}$ and emission detection at $595 \mathrm{~nm}$ with an Infinite 200Pro analyzer (Tecan).

\subsection{Quantification of neurite area}

Neurite area was measured as previously described in Stiegler et al. (2011) with minor changes as detailed below: NPC and pCN were fixed and immunostained for $\beta$ III tubulin (Tubb3) and Rbfox3 as described under "Immunofluorescence". After staining, $1 \mathrm{ml}$ PBS was filled into each well (24 well plate format), and an Array Scan VI HCS Reader (Cellomics) equipped with a Hamamatsu ORCA ER camera was used to image the plates. Five fields per well were imaged in two channels using a $10 \times$ objective $(2 \times 2$ pixel binning). Excitation/emission wave lengths of $365 \pm 50 \mathrm{~nm} / 535 \pm 45 \mathrm{~nm}$ were used to detect Rbfox3 in channel 1 and $474 \pm 40 \mathrm{~nm} / 535 \pm 45 \mathrm{~nm}$ to detect Tubb3 in channel 2. Neuronal nuclei were identified by Rbfox 3 staining as objects in channel 1 according to their size, area, shape, and intensity. The nuclear outlines were expanded in each direction, to define a virtual cell soma area (VCSA). All Tubb3 positive pixels of the field were defined as neuronal cellular structures (NCS). In an automatic calculation, the VCSAs, defined in the Rbfox3 channel, were used as a filter in the Tubb3 channel and subtracted from the NCS. The remaining pixels (NCS VCSA) in the Tubb3 channel were defined as neurite area. NPC and pCN were incubated with different concentrations of ACR on DoD19 or after 3 days in vitro, respectively. The effects on neurites were observed by measuring the neurite area after 24 and $48 \mathrm{~h}$ of exposure. By marking only neuronal nuclei with anti Rbfox3 antibody and neuronal cell bodies and neurites with anti Tubb3, we excluded non neuronal cells from neurite quantification measurements. Two independent experiments were performed with four replicates each with ESCN and 3 independent experiments with 4 replicates each with pCN.

\subsection{Calcium imaging}

Calcium plays an important role in the process of neurotrans mission and can be visualized using the calcium imaging technique (Grynkiewicz et al., 1985). Cells were cultivated on $\mathrm{HCl}$ etched $14 \mathrm{~mm}$ coated glass cover slips in 24 well plates. At certain time points of differentiation or exposure, $3 \mu \mathrm{M}$ Fura 2 AM (Tocris) were added to the culture medium and cells were incubated for $45 \mathrm{~min}$ at $37{ }^{\circ} \mathrm{C}$ and $5 \% \mathrm{CO}_{2}$. After washing with extracellular buffer ( $140 \mathrm{mM} \mathrm{NaCl}, 5 \mathrm{mM} \mathrm{KCl}, 2 \mathrm{mM} \mathrm{CaCl}_{2}, 1 \mathrm{mM}$ $\mathrm{MgCl}_{2}, 10 \mathrm{mM}$ HEPES, pH 7.4, osmolarity: 290320 mosmol/l) cover slips were transferred to the imaging chamber with extracellular buffer. Cells were imaged after $10 \mathrm{~min}$ to allow removal of intracellular acetoxymethyl groups. For functional characterization live cell video microscopy was performed on an inverted microscope (Olympus IX81). For intermittent excita tion with light of 340 and $380 \mathrm{~nm}$ (50 ms each) a Xenon arc lamp was used together with a filter wheel (MT 10) and images were taken with a monochrome charged coupled device (CCD) camera (Hamamatsu, Mega View) and Cell^R software. Relative changes of intracellular calcium concentrations $\left(\left[\mathrm{Ca}^{2+}\right]_{i}\right)$ were calculated as a ratio of the emitted light $(510 \mathrm{~nm})$ of both excitation wavelengths (f 340/380). During the experiment, cells were constantly superfused with extracellular buffer using an 8 in 1 perfusion system (Harvard Apparatus), with 8 independent reservoirs for test solutions. NT were applied in randomized protocols to reduce the impact of repeated stimulation of the same cells for $5 \mathrm{~s}$ with a concentration of $100 \mu \mathrm{M}$ each. At the end of each measurement a $5 \mathrm{~s}$ stimulus with high potassium buffer $(10 \mathrm{mM} \mathrm{NaCl}, 45 \mathrm{mM} \mathrm{KCl}, 2 \mathrm{mM} \mathrm{CaCl}$, $1 \mathrm{mM} \mathrm{MgCl}$, $10 \mathrm{mM}$ HEPES, pH 7.4, osmolarity: 290320 mos $\mathrm{mol} / \mathrm{l}$ ) was given to verify the viability of the cells and to identify neurons as only the activation of voltage gated potassium channels of healthy neurons leads to an increase of $\left[\mathrm{Ca}^{2+}\right]_{i}$. The increase of $\left[\mathrm{Ca}^{2+}\right]_{i}$ was defined as a response when the amplitude (maximum ratio after stimulation minus baseline) was higher than the mean of the baseline $+4 \times$ the standard deviation of the baseline. Only cells that responded to high $\mathrm{KCl}$ buffer stimulation were used for data analysis and the mean amplitude of all responding cells was calculated. Functionality of NPC and ESCN was assessed in three independent experiments with three technical replicates per experiment. DoD11, DoD15, DoD18 and DoD20 were analyzed, respectively. Toxicity tests were per formed using a Leica DMI 6000 microscope as described above. Therefore, NPC and pCN were incubated with different ACR concentrations for $24 \mathrm{~h}$ on DoD19 or after 3 days in vitro, respectively, and stimulated for $5 \mathrm{~s}$ in randomized protocols with Glu $(50 \mu \mathrm{M})$, acetylcholine (ACh, $100 \mu \mathrm{M})$ and GABA $(50 \mu \mathrm{M})$ as well as high $\mathrm{KCl}$ buffer at the end of each measurement to identify viable neuronal cells.

\subsection{Statistics}

All statistical analyses were performed using SPSS Version 21 (IBM Corp.) and Prism 5 (GraphPad Software). General (GLM) or generalized linear models (GENLIN) were used to analyze the effect of the applied concentrations and stability of possible effects across the biological replicates. The concentration was treated as fixed effect while the replicates were treated as random effects. According to the levels of measurement $\mathrm{F}$ or Wald $\mathrm{Chi}^{2}$ values were used to determine the significance of the treatment effect (overall effect). To account for different variances in the different treatment groups Dunnett T3 post hoc tests were used to compare the respective control condition with the various ACR concentrations. Pairwise comparisons to the control condition using the Wald type 95\% confidence interval were used to identify significant differences for the number of responders (binary variable). Statistical significance was set at $p<0.05$ and multiple comparisons were adjusted by Bonferroni correction. The $\mathrm{EC}_{50}$ values and their $95 \%$ confidence intervals were calculated by fitting symmetrical sigmoidal functions to the normalized data (i.e. expressed as percentage of controls). In the text " $n$ " means the number of biological replicates that contained several technical replicates. 
A
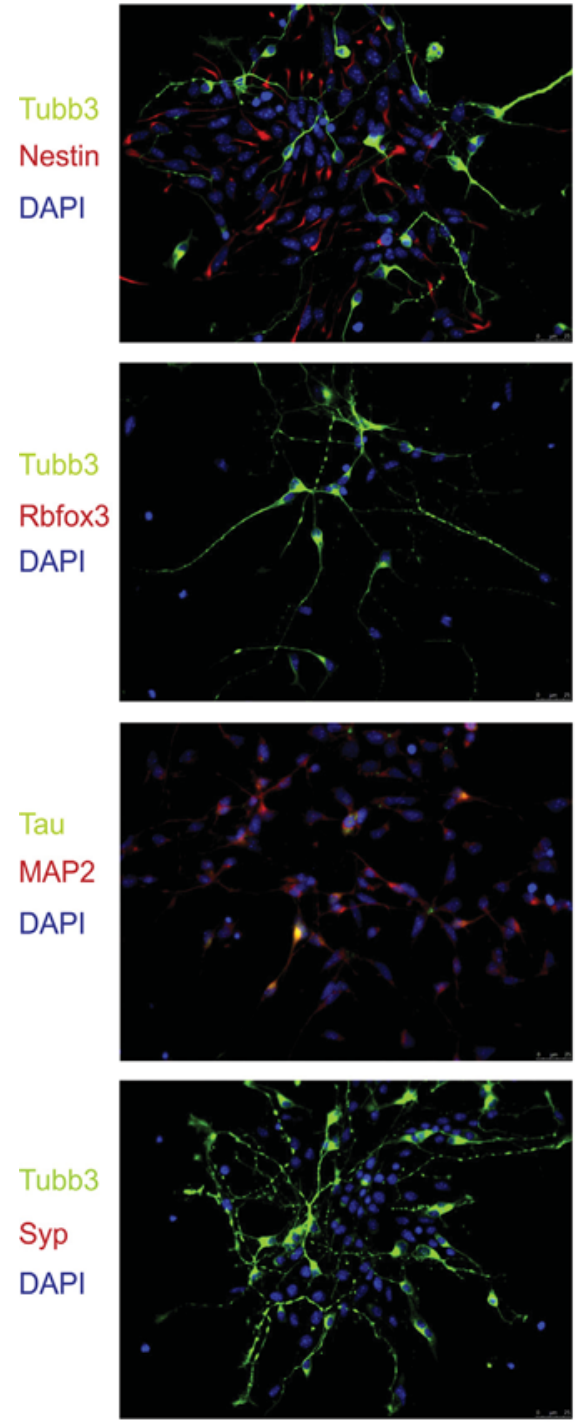

B

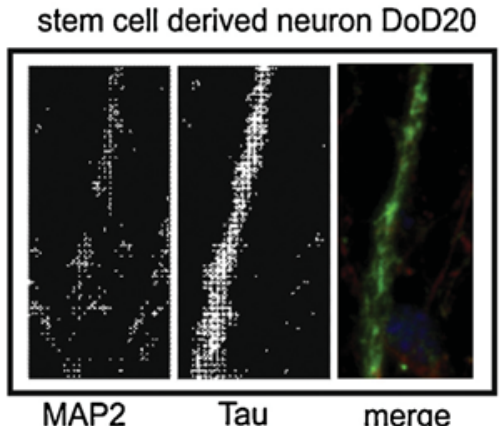

MAP2 Tau merge stem cell derived neurons DoD20
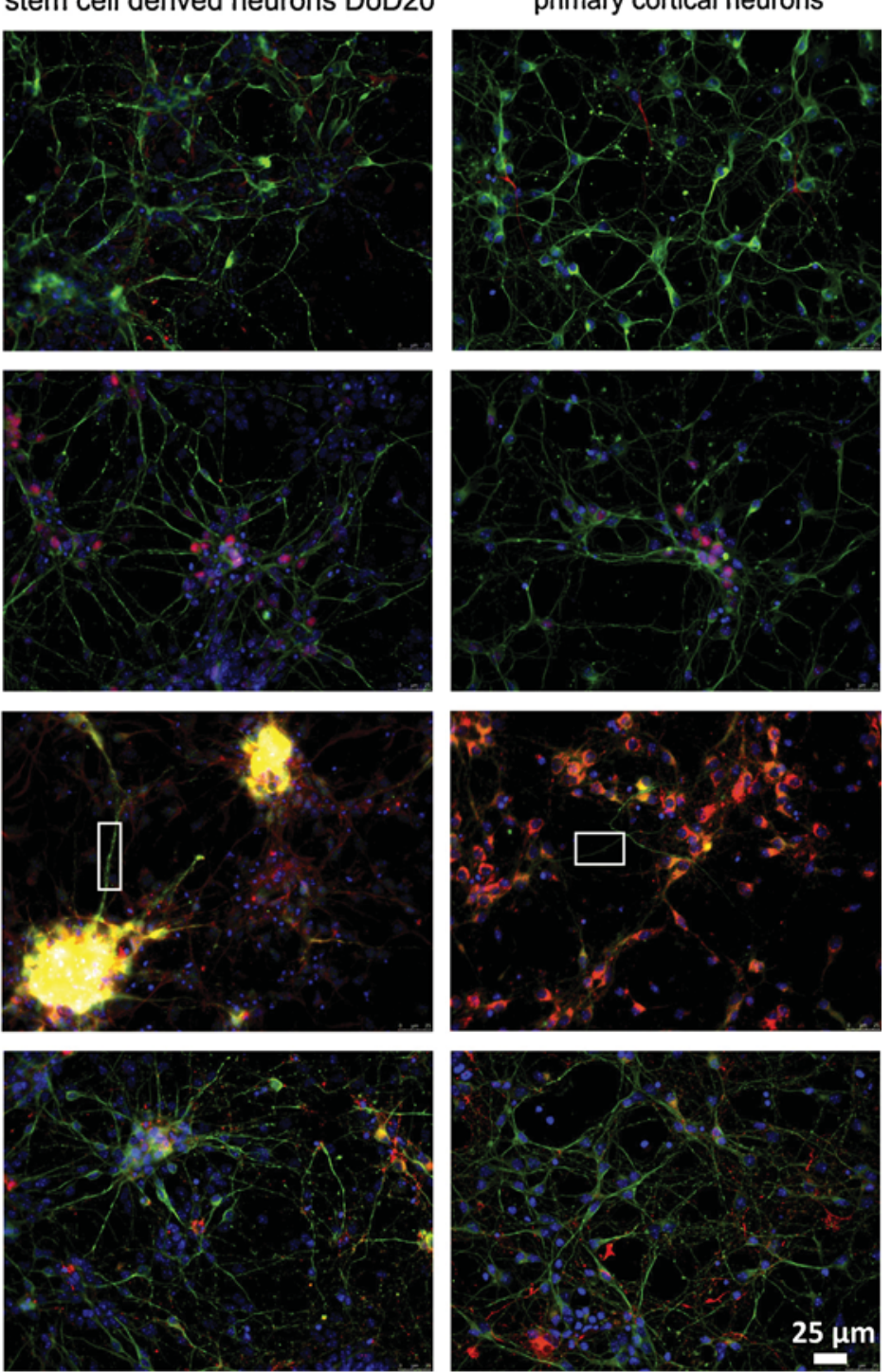

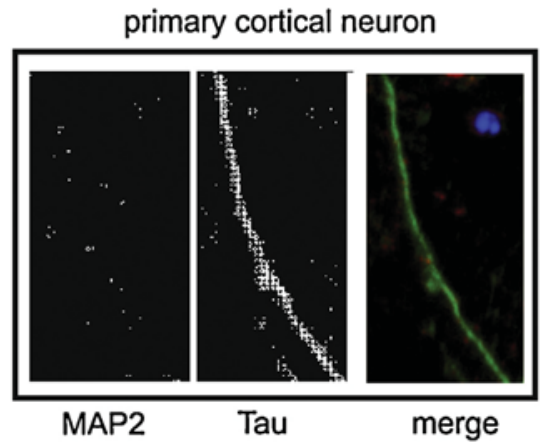

Fig. 1. Structural characterization of NPC and ESCN in comparison to mouse pCN. For analysis of the neural character of NPC and ESCN immunostainings of these cells at different DoD were compared to those of pCN at DIV 4 and pictures were taken with the same settings. The starting population (NPC) was negative for most neuronal marker proteins. The ESCN, resulting from a 20 day differentiation process were positive for Tubb3, Rbfox3, Tau, MAP2, Syp and weakly for nestin and comparable to pCN. Boxes indicate axon-like structures with weak or no MAP2, but a strong Tau signal (A). These structures are magnified in B: single channels of the ESCN neurite are shown on the left those of the pCN neurite on the right.

\section{Results}

\subsection{Similar marker expression by ESCN and $p C N$}

During the course of differentiation NPC were stained with different neuron specific antibodies and compared to pCN (Fig. 1 A).
The cellular distribution and fluorescence levels of the marker proteins found on DoD20 in ESCN were very similar to that of $\mathrm{pCN}$ at 4 days in vitro. At DoD11 NPC were positive for $\beta$ III tubulin(Tubb3) and nestin. At DoD20 the number of Tubb3 positive cells increased and nestin positive cells were still present but with weaker fluorescence. Some cells with DAPI positive nuclei showed neither 

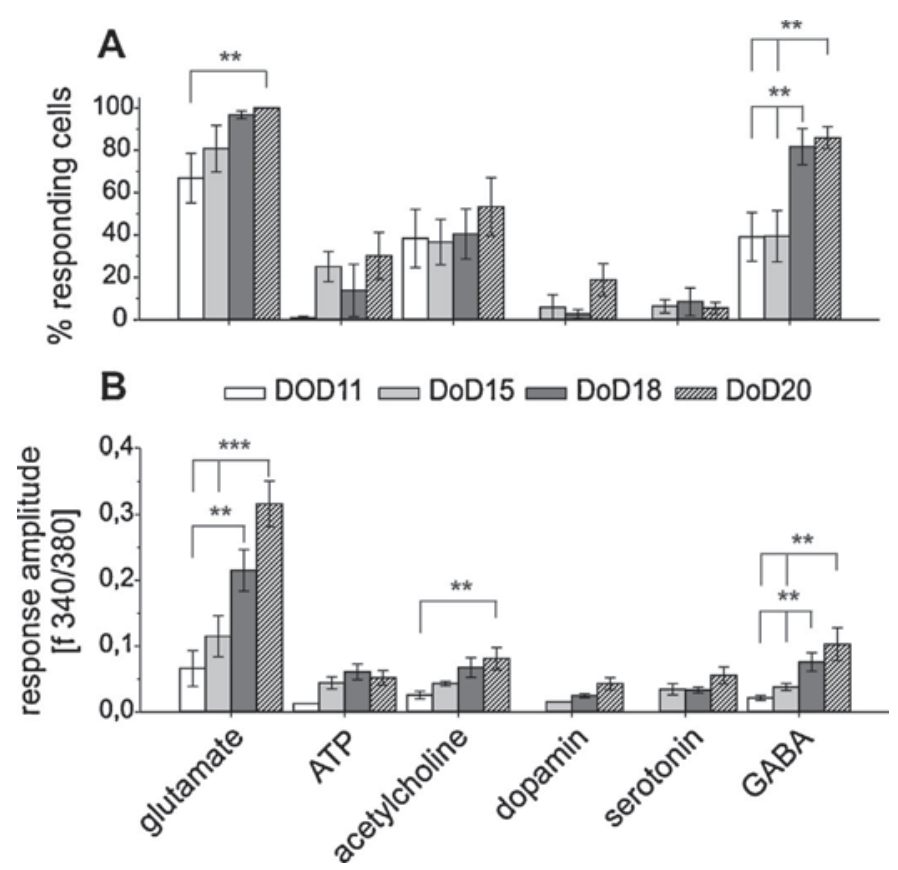

Fig. 2. Functional characterizations of NPC/ESCN. Cells were stimulated - in randomized protocols - for $5 \mathrm{~s}$ with different NT $(100 \mu \mathrm{M})$ in calcium imaging experiments to investigate functional excitability. At the end of each measurement a $5 \mathrm{~s} \mathrm{KCl}$ stimulus was given to demonstrate viability of the cells and to identify neuronal cell types. The number of responding cells (A) and response amplitudes (B) of $n=3$ ( 3 replicates each) are shown as mean \pm SEM. (number of cells analyzed: DoD11 $=56, \operatorname{DoD} 15=173, \operatorname{DoD} 18=183, \quad \operatorname{DoD} 20=286 ;{ }^{* *} p \leq 0.01,{ }^{* * *} p \leq 0.001$, Dunnett-T3 post-hoc tests).

Tubb3, nor nestin staining. At DoD11 NPC showed no or weak fluorescence for Rbfox3 (NeuN), Tau or synaptophysin (Syp), but were positive for MAP2. At DoD20 a high number of Rbfox3 positive cells was observed. Tau and Syp were present in the majority of these cells. We detected neurites of ESCN being strongly stained for Tau but much weaker for MAP2 (Fig. $1 \mathrm{~A}$ boxes and $\mathrm{B}$ ). In $\mathrm{pCN}$ stainings we found neurites showing only fluorescence signals for Tau but not for MAP2 (Fig. 1B).

\subsection{NPC and ESCN respond to various NT}

Clear differentiation associated increases in the number of responding cells and mean response amplitudes were obtained for Glu, ACh and GABA (Fig. 2). When the cells were stimulated with Glu on DoD11, 67\% (46/56 cells) showed a response to this stimulus. The number of responding cells increased significantly until DoD20 to $100 \%$ (286/286 cells). In the beginning of the differentiation process (DoD11) we found no cell being activated by a serotonin nor a dopamine stimulus and $0.8 \%$ ( $1 / 56$ cells) by ATP. During the following days these percentages did not change significantly. However, slight increases were found for these three NT. At DoD11 we observed that 39\% (31/56 cells) of the cells responded with an increase in $\left[\mathrm{Ca}^{2+}\right]_{i}$ when applying GABA. The number of these cells increased significantly at DoD18 with $82 \%$ ( $153 / 183$ cells) and DoD20 with $86 \%$ (250/286 cells). Also the relative response amplitudes for Glu, ACh and GABA increased significantly during differentiation: After a Glu stimulus the mean amplitude increased significantly from $0.07 \pm 0.03$ at DoD1 1 to $0.32 \pm 0.04$ at DoD20. ACh evoked a mean amplitude of $0.03 \pm 0.01$ at DoD11 and one of $0.08 \pm 0.02$ at DoD20. After a GABA stimulus the mean amplitude at DoD11 reached $0.02 \pm 0.004$ and was significantly higher at DoD18 $(0.08 \pm 0.01)$ and DoD20 $(0.10 \pm 0.03)$. We could not observe any significant difference in the mean amplitude for ATP, dopamine or serotonin. Representative response curves of NPC on different DoD and ESCN are shown with two exemplary traces each (Fig. 3A). These traces illustrate the increase in the response peaks with proceeding differentiation. Single trace analysis also shows that response behaviors of different cells varied (Fig. 3A).

\subsection{Cytotoxicity and neurite degeneration by exposure to ACR in ESCN and $p C N$}

After $24 \mathrm{~h}$ ACR exposure the cell viability assay revealed an $\mathrm{EC}_{50}$ of $5.7 \mathrm{mM}$ (CI: $4.96 .4 \mathrm{mM}$ ) for pCN. The lowest ACR concentration with a significant effect on cell viability in pCN was $1.6 \mathrm{mM}$. Here the cell viability was reduced to $80 \%$ compared to the control condition $(p=0.02)$. In $\mathrm{ESCN}$ an $\mathrm{EC}_{50}$ of $7.6 \mathrm{mM}(\mathrm{CI}: 3.711 .5 \mathrm{mM})$ was observed and none of the investigated concentrations had a significant effect on cell viability. The highest concentration of

A
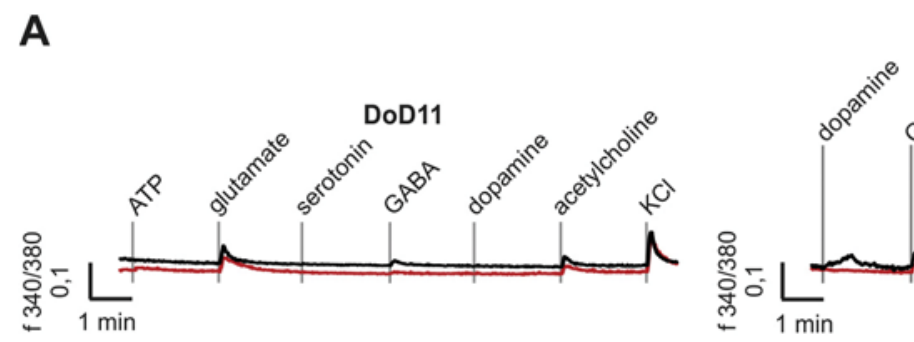

DoD18

B

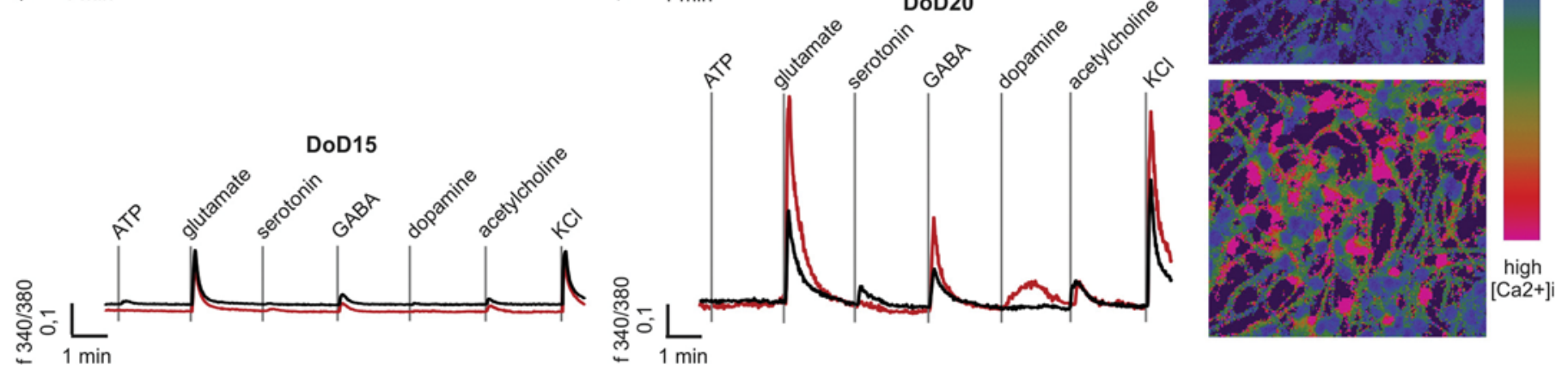

Fig. 3. Response behavior of NPC/ESCN after stimulation with NT. Cells were stimulated for $5 \mathrm{~s}$ with different NT (100 $\mu \mathrm{M})$ in calcium imaging experiments. The order of stimuli was randomized. At the end of each measurement a $5 \mathrm{~s} \mathrm{KCl}$ stimulus was applied to identify neuronal cells and to test viability of the cells. Exemplary traces of two single cells per DoD illustrate different response behaviors and responses of these cells to different stimuli (A). False color images of resting (left) and stimulated (right) ESCN. Blue color indicates a low $\left[\mathrm{Ca}^{2+}\right]_{i}$ and pink a high $\left[\mathrm{Ca}^{2+}\right]_{\mathrm{i}}(\mathrm{B})$. 

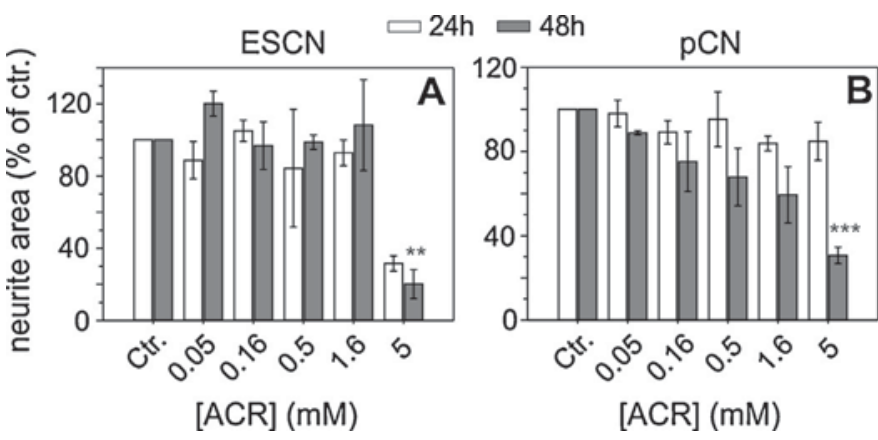

Fig. 4. Neurotoxic effects of ACR on neurites of ESCN and pCN. Cells were incubated with different concentrations of ACR for $24 \mathrm{~h}$ (white bars) or $48 \mathrm{~h}$ (grey bars) respectively. Neurite area of ESCN was calculated of $n=2$ with 4 replicates at each time point (A) and of $\mathrm{pCN}$ for $n=3$ with 4 replicates at each time point (B). (mean $\pm \mathrm{SEM} ;{ }^{*} p \leq 0,05 ;{ }^{* *} p \leq 0.005 ;{ }^{* * *} p \leq 0.001$, Dunnett-T3 post-hoc tests).

$5 \mathrm{mM}$ induced a reduction to $85 \%$ by trend. First significant effects on neurite area were observed when ESCN or pCN were exposed to $5 \mathrm{mM}$ ACR for $48 \mathrm{~h}$. Compared to the control condition, the neurite area of ESCN decreased by $80 \%$ after $48 \mathrm{~h}$ of ACR incubation (Fig. 4A). When pCN were incubated along with $5 \mathrm{mM} \mathrm{ACR}$ for $48 \mathrm{~h}$ the neurite area was reduced by $69 \%$ (Fig. 4B). There was no significant effect after $24 \mathrm{~h} \mathrm{ACR}$ exposure. However, the neurite area of ESCN was reduced after incubation with $5 \mathrm{mM}$ by a clear trend.

\subsection{ACR incubation alters NT response behavior in ESCN and pCN}

Because NPC/ESCN responded to a broad spectrum of NT we asked whether this cell type could be used to explore the effects of ACR on NT induced calcium responses as an indicator of neurotransmission. We found that ACR affected the response amplitude at the lowest concentration of $0.5 \mathrm{mM}$. Similar effects of ACR were observed for both cell types with the strongest influence for Glu. We could not detect any significant difference in the number of responding ESCN, except for $5 \mathrm{mM}$ ACR. Here, a clear decline in the number of responding cells for ACh (from 78 to $26 \%$ responding cells; Fig. 5A) and GABA stimuli (from 85 to $45 \%$ responding cells; Fig. 5B) was observed. The number of GABA responsive $\mathrm{pCN}$ reduced to $23 \%$ (Fig. 5D) after incubation with $5 \mathrm{mM}$ ACR. A decrease to $54 \%$ Glu responsive cells was observed after exposure to $5 \mathrm{mM} \mathrm{ACR}$ in pCN, and to $67 \%$ after exposure to 1.6 mM ACR (Fig. 5E). ACh was not investigated in $\mathrm{pCN}$ as this cell type is not responsible to ACh due to its cortical origin. The basal calcium level of both cell types was not affected by all concentrations of ACR (Fig. $5 \mathrm{~F}$ and $\mathrm{G}$ ). After ACR exposure the mean amplitudes of ESCN for ACh and Glu stimuli were significantly decreased in a concentration dependent manner (Fig. 6A and C): at $0.5 \mathrm{mM}$ ACR the ACh amplitude was reduced to $71 \%$, at $1.6 \mathrm{mM}$ to $57 \%$ and at $5 \mathrm{mM}$ ACR to $26 \%$ of the control condition. The Glu induced response amplitudes were decreased to $66 \%$ after incubation with $0.5 \mathrm{mM} \mathrm{ACR}$, to $62 \%$ with $1.6 \mathrm{mM}$ and to $47 \%$ with $5 \mathrm{mM}$ ACR (Fig. 6B). The exposure with $1.6 \mathrm{mM}$ ACR led to a reduction of the mean amplitude to $67 \%$ after a $\mathrm{KCl}$ stimulus and with $5 \mathrm{mM}$ ACR to 59\% (Fig. 6D). There was no significant change in the $\mathrm{KCl}$ induced mean amplitude after incubation with $0.5 \mathrm{mM}$ ACR. Stimulating the ESCN with GABA after exposure to $0.5 \mathrm{mM}$ ACR led to a 59\% higher mean response amplitude compared to the control cells. In $\mathrm{pCN}$ we observed a concentration dependent reduction of Glu and $\mathrm{KCl}$ induced mean amplitudes (Fig. $6 \mathrm{~F}$ and $\mathrm{G}$ ): after exposure to $0.5 \mathrm{mM} \mathrm{ACR}$ the mean Glu evoked amplitude was decreased to $71 \%$, after exposure to $1.6 \mathrm{mM}$ to $53 \%$ and after exposure to $5 \mathrm{mM}$ to $26 \%$ in comparison to the control cells. The $\mathrm{KCl}$ induced mean amplitude was decreased to $81 \%$ after

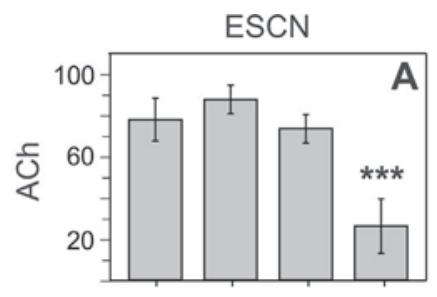

pCN
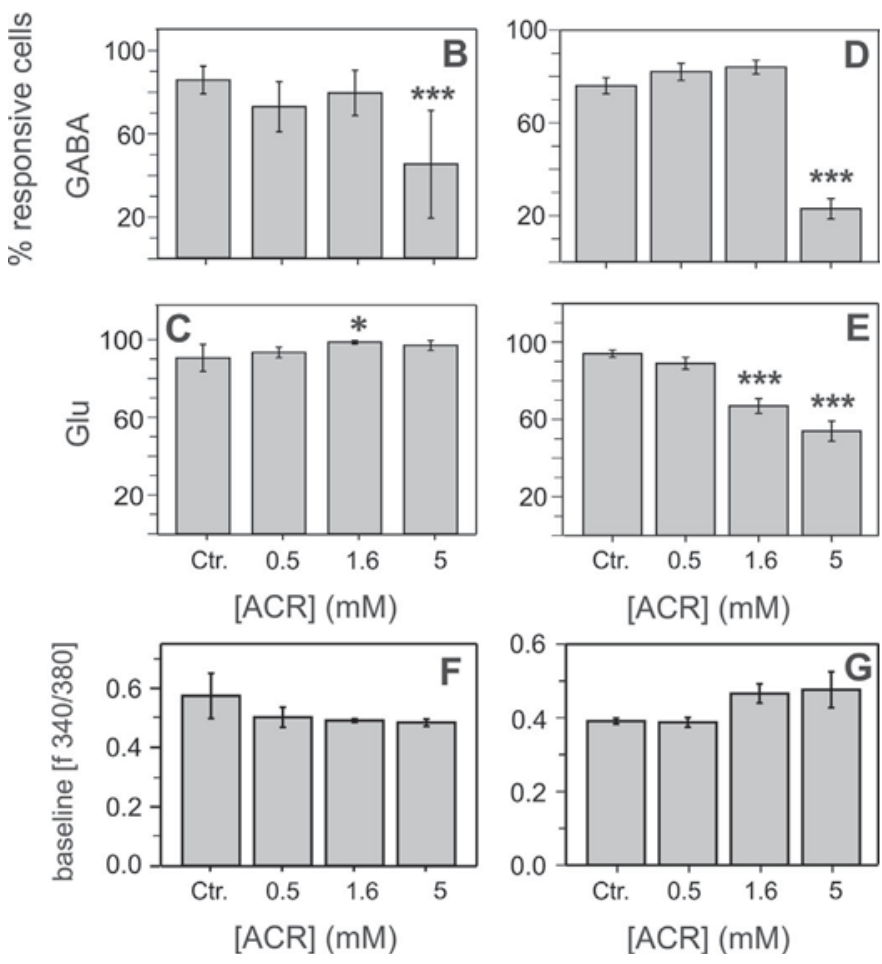

Fig. 5. Effects of $24 \mathrm{~h}$ exposure to ACR on the number of cells responding to NTstimuli. ESCN and PCN were incubated with different concentrations of ACR for $24 \mathrm{~h}$. The number of responsive cells was determined in calcium imaging experiments for $\mathrm{ACh}(\mathrm{A}), \mathrm{GABA}(\mathrm{B}, \mathrm{D})$ and $\mathrm{Glu}(\mathrm{C}, \mathrm{E})$. Only $\mathrm{KCl}$ responsive cells were analyzed $(=100 \%)$. Shown are mean \pm SEM of $n=2$ (2 measurements each) for ESCN and $n=3$ (1-2 measurements each) for PCN (number of ESCN analyzed: Ctr. = 96, $0.5 \mathrm{mM}=54, \quad 1.6 \mathrm{mM}=93,5 \mathrm{mM}=41$; number of $\mathrm{pCN}$ analyzed: $\mathrm{Ctr} .=150$, $0.5 \mathrm{mM}=107,1.6 \mathrm{mM}=153,5 \mathrm{mM}=93 ;{ }^{*} p \leq 0.05 ;{ }^{* *} p \leq 0.005 ;{ }^{* * *} p \leq 0.001$, WaldChi-Square test) There was no significant change in basic calcium levels after ACR exposure (F, G; Dunnett-T3 post-hoc tests).

incubation with $0.5 \mathrm{mM} \mathrm{ACR}$, to $65 \%(p \leq 0.001)$ after incubation with $1.6 \mathrm{mM}$ and to $30 \%$ after incubation with $5 \mathrm{mM}$ ACR. When pCN were incubated with $5 \mathrm{mM}$ ACR the mean amplitude induced by GABA was decreased to $30 \%$. A $26 \%$ increase of the mean GABA induced response amplitude after exposure to $0.5 \mathrm{mM} \mathrm{ACR}$, as observed with ESCN, could be detected with $\mathrm{pCN}$ by trend. An acute exposure to ACR itself did not change $\left[\mathrm{Ca}^{2+}\right]_{\mathrm{i}}$ (Fig. $6 \mathrm{H}$ ).

\section{Discussion}

Recently a mouse ESC based in vitro system has been established that allows differentiation to neuronal cells (ESCN) (Zimmer et al., 2011). ESCN have been shown to express neuron specific markers and to be electrophysiologically excitable. In the present study we demonstrate that ESCN gain neuronal function ality during the differentiation process. Moreover, we illustrate that ACR not only causes structural alterations, but decreases NT induced response amplitudes at even lower concentrations. Similar results were obtained for ESCN and pCN. 

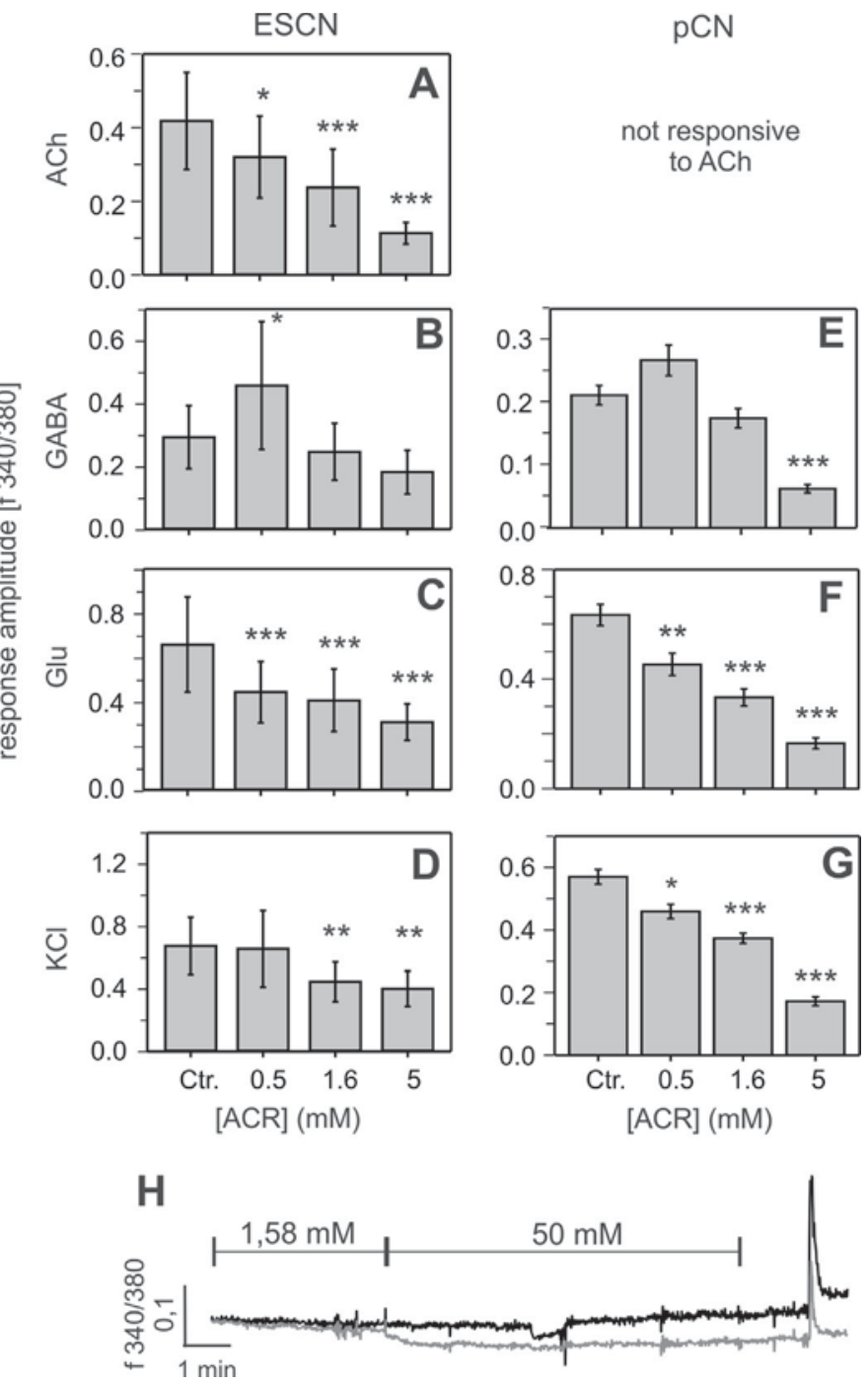

Fig. 6. Effects of $24 \mathrm{~h}$ exposure to ACR on NT-evoked response amplitudes of ESCN and pCN. Cells were incubated with different ACR-concentrations for $24 \mathrm{~h}$. The mean response amplitudes \pm SEM of ACh- (A), GABA- (B, E), Glu- (C, F) and KCl- (D, G) stimuli are shown of $n=2(2$ measurements each) for ESCN (A-D) and of $n=3(1-2$ measurements each) for pCN (E-G); (number of $\mathrm{ESCN}$ analyzed: Ctr. $=96,0.5 \mathrm{mM}=54,1.6 \mathrm{mM}=93,5 \mathrm{mM}=41$; number of pCN analyzed: $\mathrm{Ctr}$. $=150,0.5 \mathrm{mM}=107,1.6 \mathrm{mM}=153,5 \mathrm{mM}=93$; ${ }^{*} p \leq 0.05 ;{ }^{* *} p \leq 0.005 ;{ }^{* * *} p \leq 0.001$, Dunnett-T3 post-hoc tests). Exemplary traces of two cells (H) demonstrate that neither a 4 min stimulation with 1.6 mM ACR nor a 7 min stimulation with $50 \mathrm{mM}$ ACR changed $\left[\mathrm{Ca}^{2+}\right]_{\mathrm{i}}$.

\subsection{Immunostaining confirms similar marker localization in ESCN and $p C N$}

Immunocytochemistry analysis clearly demonstrates that differentiated ESCN possess important characteristics of neurons. Compared to the $\mathrm{pCN}$ from mouse embryos the cellular distribu tion and appearance of these proteins were similar in the two investigated cell types. Rbfox3 is expressed exclusively in the nuclei of post mitotic neurons (Mullen et al., 1992) and signals of this marker could be detected in NPC and ESCN nuclei as well. Moreover, we found neurites with strong Tau and weak MAP2 signals in ESCN. In mature neurons MAP2 is absent in axons and located only somato dendritically, whereas Tau is mainly present in axons (Bernhardt and Matus, 1984; Binder et al., 1985; Dotti et al., 1987; Kosik and Finch, 1987; Mandell and Banker, 1995). In the developing neuron, Tau segregates into axons and MAP2 into dendrites right after axogenesis (Matus, 1990). Therefore, ESCN seem to be still in the process of axogenesis whereas pCN already finished this process. ESCN also express presynaptic structures as shown by the positive signal for Syp, a protein of presynaptic vesicles (Wiedenmann and Franke, 1985) and involved in calcium dependent NT release (Rehm et al., 1986). Besides neurons, there are also few non neuronal cells which were identified by their stained nuclei and being negative for any neuronal marker. Some of these cells were positive for nestin. Similar cell types could also be observed in pCN cultures. As nestin is also expressed in glial cells (Schmidt Kastner and Humpel, 2002), these findings are consistent with the results of Zimmer et al. (2011), who found astrocyte markers in NPC cultures, such as gfap and glutamine synthetase, as well as markers for a small subpopulation of cells showing smooth muscle features.

\subsection{ESCN are functional neurons}

ESCN express various functional NT receptors which mediate an increase in the membrane potential, as confirmed by specific stimulation in calcium imaging experiments. Across the course of differentiation the number of responding cells increased for most of the NT and also the mean amplitude increased over time. These results argue for an ongoing differentiation process towards 
a neuronal phenotype. The NT serotonin and dopamine showed an excitatory effect in our experiments. This suggests that $5 \mathrm{HT}_{3}$ and $5 \mathrm{HT}_{2}$ receptors and those of the $\mathrm{D}_{1}$ family are expressed in NPC and ESCN because only these receptors evoke an excitatory receptor potential and an increase of $\left[\mathrm{Ca}^{2+}\right]_{\mathrm{i}}$ (Maricq et al., 1991; Nichols and Nichols, 2008; Undie and Friedman, 1990). Throughout the whole differentiation process also GABA stimulation showed a strong excitatory effect. Therefore, NPC and ESCN express $G_{A B A}$ receptors that are the only GABA receptors accompanied with an altered chloride homeostasis during maturation leading to responses in calcium imaging experiments. This receptor has a depolarizing effect in cortical progenitors and immature neurons (Ben Ari, 2002; LoTurco et al., 1995) such as the pCN analyzed in this study. Thus, we suggest that our ESCN are a culture with cells of different maturation stages, similar to $\mathrm{pCN}$.

The strongest increase in response amplitudes during the differentiation process was observed for Glu. Glu neurotransmission can be mediated by various receptor subtypes, including ionotropic NMDA, AMPA and kainate receptors as well as metabotropic Glu receptors (Hollmann and Heinemann, 1994). From a previous study it is known that ESCN express NMDA and AMPA receptors (Zimmer et al., 2011). However, which specific receptor subtype is responsible for the observed calcium response by Glu remains to be determined by specific inhibitors and protein expression analysis.

Cells used and measured in calcium imaging experiments represent a random sample of the entire NPC/ESCN culture. The observed culture sections were chosen due to the morphology of the cells, preferring neuronal phenotypes. According to single cell traces these sections usually contained cells of different differentiation stages, as not all response amplitudes, especially those to $\mathrm{KCl}$ and $\mathrm{Glu}$, were equal. This observation is in line with the findings of the immunostaining experiments: at DoD20 we found fully differentiated neurons with strong Rbfox3 signals as well as cells that showed weaker Rbfox3 signals or that expressed Nestin along with Tubb3.

\subsection{ACR impairs neuronal function after short term exposure}

The most striking result of our experiments is that ACR at concentrations of $0.5 \mathrm{mM}$ reduces the mean response amplitude of Glu induced increase of cytosolic calcium in ESCN and pCN. This reduction is not accompanied by a reduction of the fraction of responding cells. Recently, a mechanism has been discussed how chemical reactions with glutamatergic NMDA receptors may reduce their functionality. These results suggest that ACR might modulate the affinity of glutamatergic receptors towards their ligand especially at low concentrations when voltage gated potassium channels were not or less affected. ACR has an electrophilic double bond (Friedman, 2003). It has been suggested that it forms covalent bonds with soft nucleophiles (e.g. SH of cysteine) in synaptic compartments (LoPachin and Gavin, 2012). This interaction is well documented for NO (LoPachin and Barber, 2006). Therefore, ACR may, similarly to the physiological NO, also bind to cysteine residues (e.g. Cys 79 and Cys 208 at the NR1 receptor subunit). In contrast to NO, binding by ACR may be irreversible, thereby decreasing the affinity to the ligand. Further experiments should elucidate this mode of action.

There is already convincing evidence from in vivo studies in rats and humans that ACR impairs neuronal function (Crofton et al., 1996; Goffeng et al., 2008). However, the effects of this neurotoxin on NT receptors in neurons have not yet been studied. Research on ACR and its effects on neuronal function are based on ligand binding assays or the secretion and re uptake of NT (Agrawal et al., 1981; Bondy et al., 1981; LoPachin et al., 2004). Moreover, Nordin Andersson et al. (2003) reported increased ACh evoked, IP $_{3}$ mediated response amplitudes in human SH SY5Y neuroblastoma cells after $72 \mathrm{~h}$ ACR exposure. They suggested that an ACR induced increased basal $\left[\mathrm{Ca}^{2+}\right]_{i}$ resulted in an elevated uptake of $\mathrm{Ca}^{2+}$ into intracellular stores which in turn led to increased amplitudes. In our study we could not observe this elevation of basal $\mathrm{Ca}^{2+}$ levels and detected a concentration dependent decrease of ACh induced response amplitudes. A study of Lappe Siefke et al. (2009) reported an increase of $G_{A B A}$ receptors in Purkinje cells of mice with cerebellar ataxia together with an increased inhibitory postsynaptic current in these cells. ACR exposure causes cerebellar ataxia accompanied by an abnormal morphology of GABAergic Purkinje cells (Shi et al., 2012). This mode of action on GABAergic neurotransmis sion might be reflected in the increase of GABA evoked mean response amplitudes after incubation with $0.5 \mathrm{mM} \mathrm{ACR}$ and thus, the ESCNs might be a suitable in vitro system to follow up this in vivo observation of Shi et al. (2012).

Compared to previous in vitro studies investigating the effects of ACR on neurites (Hardelauf et al., 2011; Martenson et al., 1995; Nordin Andersson et al., 1998, 2003) as an indicator of structural neurotoxicity, ESCN as well as pCN appear to be more resistant to ACR. Using the neuroblastoma cell line SH SY5Y, Hardelauf et al. (2011) reported that $1 \mathrm{mM}$ ACR clearly compromised a network of neurites. Another study (Nordin Andersson et al., 2003) also investigated neurite degeneration in SH SY5Y cells and observed neurite degenerative effects already at $0.25 \mathrm{mM}$ after $24 \mathrm{~h}$. The higher cell density in the NPC/ESCN cultures as well as the heterogeneity with respect to the cell type might explain such differences. However, the relative resistance of ESCN to neurite effects of ACR agrees with data from pCN as well as from human LUHMES cells that also did not indicate specific neurite degeneration (Krug et al., 2013a,b). Both cell types pCN and ESCN showed similar results after exposure to ACR. ESCN may be a useful tool to analyze neurotoxic effects and may replace primary neurons in future experiments. ESCN are easy to differentiate and pre differentiated cells can be stored in large batches in liquid nitrogen and used for different experiments to reduce variance. ESCN provide a variety of neuron specific functions and therefore can be used to analyze a broad spectrum of effects.

\section{Conclusion}

In the present study we have shown that mouse ESCN have similar functional properties as pCN from 16 day old mouse embryos. Immunostaining illustrated also similar patterns of neuronal markers. A specific advantage of ESCN is that they can be established from cryopreserved precursor cells (NPC). Therefore, ESCN may be a good alternative cell system to primary neurons to study neurotoxic effects and effect modes in vitro.

\section{Conflict of interest}

The authors declare that there are no conflicts of interest.

\section{Transparency document}

The Transparency document associated with this article can be found in the online version.

\section{Acknowledgments}

We gratefully thank Liudmila Efremova for technical assistance with the Cellomics setup and Heidrun Leisner for the pre differentiation of NPC. The project was funded by grants from EU (FP7 ESNATS), DFG (RTG1331), BMBF (NEURITOX717/13 (ML), 
0315545B (VH)) and Land Baden Württemberg (866/12). Sponsors had no involvement in study design; collection, analysis and interpretation of data; the writing of the manuscript or the decision to submit the manuscript for publication.

\section{References}

Agrawal AK, Seth PK, Squibb RE, Tilson HA, Uphouse LL, Bondy SC. Neurotransmitter receptors in brain regions of acrylamide-treated rats. I: Effects of a single exposure to acrylamide. Pharmacol Biochem Behav 1981;14:527-31.

Bear MF, Connors BW, Paradiso MA. Neurowissenschaften - Ein grundlegendes Lehrbuch für Biologie, Medizin und Psychologie. 3rd ed. Berlin: Spektrum Akademischer Verlag; 2008.

Ben-Ari Y. Excitatory actions of gaba during development: the nature of the nurture. Nat Rev 2002;3:728-39.

Bernhardt R, Matus A. Light and electron microscopic studies of the distribution of microtubule-associated protein 2 in rat brain: a difference between dendritic and axonal cytoskeletons. J Comp Neurol 1984;226:203-21.

Binder LI, Frankfurter A, Rebhun LI. The distribution of tau in the mammalian central nervous system. J Cell Biol 1985;101:1371-8.

Bondy SC, Tilson HA, Agrawal AK. Neurotransmitter receptors in brain regions of acrylamide-treated rats. II: Effects of extended exposure to acrylamide. Pharmacol Biochem Behav 1981;14:533-7.

Brustle 0. Developmental neuroscience: miniature human brains. Nature 2013:501:319-20.

Collins FS, Gray GM, Toxicology Bucher JR. Transforming environmental health protection. Science 2008;319:906-7.

Crofton KM, Padilla S, Tilson HA, Anthony DC, Raymer JH, MacPhail RC. The impact of dose rate on the neurotoxicity of acrylamide: the interaction of administered dose, target tissue concentrations, tissue damage, and functional effects. Toxicol Appl Pharmacol 1996;139:163-76.

Defranchi E, Novellino A, Whelan M, Vogel S, Ramirez T, van Ravenzwaay B, et al. Feasibility assessment of micro-electrode chip assay as a method of detecting neurotoxicity in vitro. Front Neuroeng 2011;4:6.

Dinh ND, Chiang YY, Hardelauf H, Baumann J, Jackson E, Waide S, et al. Microfluidic construction of minimalistic neuronal co-cultures. Lab Chip 2013;13:1402-12.

Dotti CG, Banker GA, Binder LI. The expression and distribution of the microtubuleassociated proteins tau and microtubule-associated protein 2 in hippocampal neurons in the rat in situ and in cell culture. Neuroscience 1987;23:121-30.

Friedman M. Chemistry, biochemistry, and safety of acrylamide. A review. J Agric Food Chem 2003;51:4504-26.

Fritsche E, Cline JE, Nguyen NH, Scanlan TS, Abel J. Polychlorinated biphenyls disturb differentiation of normal human neural progenitor cells: clue for involvement of thyroid hormone receptors. Environ Health Perspect 2005;113:871-6.

Gassmann K, Abel J, Bothe H, Haarmann-Stemmann T, Merk HF, Quasthoff KN, et al. Species-specific differential AhR expression protects human neural progenitor cells against developmental neurotoxicity of PAHs. Environ Health Perspect 2010;118:1571-7.

Goffeng LO, Heier MS, Kjuus H, Sjoholm H, Sorensen KA, Skaug V. Nerve conduction, visual evoked responses and electroretinography in tunnel workers previously exposed to acrylamide and $\mathrm{N}$-methylolacrylamide containing grouting agents. Neurotoxicol Teratol 2008;30:186-94.

Grynkiewicz G, Poenie M, Tsien RY. A new generation of $\mathrm{Ca}^{2+}$ indicators with greatly improved fluorescence properties. J Biol Chem 1985;260:3440-50.

Hardelauf H, Sisnaiske J, Taghipour-Anvari AA, Jacob P, Drabiniok E, Marggraf U, et al. High fidelity neuronal networks formed by plasma masking with a bilayer membrane: analysis of neurodegenerative and neuroprotective processes. Lab Chip 2011;11:2763-71.

Hollmann M, Heinemann S. Cloned glutamate receptors. Annu Rev Neurosci 1994; $17: 31-108$

Howard AS, Bucelli R, Jett DA, Bruun D, Yang D, Lein PJ. Chlorpyrifos exerts opposing effects on axonal and dendritic growth in primary neuronal cultures. Toxicol Appl Pharmacol 2005;207:112-24.

Huang F, Schneider JS. Effects of lead exposure on proliferation and differentiation of neural stem cells derived from different regions of embryonic rat brain. Neurotoxicology 2004;25:1001-12.

Kadereit S, Zimmer B, van Thriel C, Hengstler JG, Leist M. Compound selection for in vitro modeling of developmental neurotoxicity. Front Biosci (Landmark Ed) 2012; 17:2442-60.

Kandel ER, Schwartz JC, Jessell TM. Principles of neural science. 4th ed. New York: Mcgraw-Hill Professional; 2000.

Klemm M, Schrattenholz A. Neurotoxicity of active compounds - establishment of hESC-lines and proteomics technologies for human embryo- and neurotoxicity screening and biomarker identification. ALTEX 2004;21(Suppl. 3):41-8.

Kosik KS, Finch EA. MAP2 and tau segregate into dendritic and axonal domains after the elaboration of morphologically distinct neurites: an immunocytochemical study of cultured rat cerebrum. J Neurosci 1987;7:3142-53.

Krug AK, Balmer NV, Matt F, Schonenberger F, Merhof D, Leist M. Evaluation of a human neurite growth assay as specific screen for developmental neurotoxicants. Arch Toxicol 2013a;87:2215-31.

Krug AK, Kolde R, Gaspar JA, Rempel E, Balmer NV, Meganathan K, et al. Human embryonic stem cell-derived test systems for developmental neurotoxicity: a transcriptomics approach. Arch Toxicol 2013b;87:123-43.
Lancaster MA, Renner M, Martin CA, Wenzel D, Bicknell LS, Hurles ME, et al. Cerebral organoids model human brain development and microcephaly. Nature 2013;501:373-9.

Lappe-Siefke C, Loebrich S, Hevers W, Waidmann OB, Schweizer M, Fehr S, et al. The ataxia (axJ) mutation causes abnormal GABAA receptor turnover in mice. PLoS Genet 2009;5:e1000631.

Leist M, Bremer S, Brundin P, Hescheler J, Kirkeby A, Krause KH, et al. The biological and ethical basis of the use of human embryonic stem cells for in vitro test systems or cell therapy. ALTEX 2008a;25:163-90.

Leist M, Hartung T, Nicotera P. The dawning of a new age of toxicology. ALTEX 2008b;25:103-14.

LoPachin RM, Barber DS. Synaptic cysteine sulfhydryl groups as targets of electrophilic neurotoxicants. Toxicol Sci 2006;94:240-55

LoPachin RM, Gavin T. Molecular mechanism of acrylamide neurotoxicity: lessons learned from organic chemistry. Environ Health Perspect 2012;120: 1650-7.

LoPachin RM, Schwarcz AI, Gaughan CL, Mansukhani S, Das S. In vivo and in vitro effects of acrylamide on synaptosomal neurotransmitter uptake and release. Neurotoxicology 2004;25:349-63.

LoTurco JJ, Owens DF, Heath MJ, Davis MB, Kriegstein AR. GABA and glutamate depolarize cortical progenitor cells and inhibit DNA synthesis. Neuron 1995;15:1287-98.

Mandell JW, Banker GA. The microtubule cytoskeleton and the development of neuronal polarity. Neurobiol Aging 1995;16:229-37 discussion 38.

Maricq AV, Peterson AS, Brake AJ, Myers RM, Julius D. Primary structure and functional expression of the 5HT3 receptor, a serotonin-gated ion channel. Science 1991;254:432-7.

Martenson CH, Sheetz MP, Graham DG. In vitro acrylamide exposure alters growth cone morphology. Toxicol Appl Pharmacol 1995;131:119-29.

Matus A. Microtubule-associated proteins and the determination of neuronal form. J Physiol (Paris) 1990;84:134-7.

Mullen RJ, Buck CR, Smith AM. NeuN, a neuronal specific nuclear protein in vertebrates. Development 1992;116:201-11.

Nichols DE, Nichols CD. Serotonin receptors. Chem Rev 2008;108:1614-41.

Nordin-Andersson M, Forsby A, Heldring N, Dejongh J, Kjellstrand P, Walum E. Neurite degeneration in differentiated human neuroblastoma cells. Toxicol In Vitro 1998; $12: 557-60$.

Nordin-Andersson M, Walum E, Kjellstrand P, Forsby A. Acrylamide-induced effects on general and neurospecific cellular functions during exposure and recovery. Cell Biol Toxicol 2003:19:43-51.

Rehm H, Wiedenmann B, Betz H. Molecular characterization of synaptophysin, a major calcium-binding protein of the synaptic vesicle membrane. EMBO J 1986;5:535-41.

Rohlman DS, Lucchini R, Anger WK, Bellinger DC, van Thriel C. Neurobehavioral testing in human risk assessment. Neurotoxicology 2008;29:555-66.

Schmidt-Kastner R, Humpel C. Nestin expression persists in astrocytes of organotypic slice cultures from rat cortex. Int J Dev Neurosci 2002;20:29-38

Schmuck G, Schluter G. An in vitro model for toxicological investigations of environmental neurotoxins in primary neuronal cell cultures. Toxicol Ind Health 1996:12:683-96

Shi J, Ma Y, Zheng M, Ruan Z, Liu J, Tian S, et al. Effect of sub-acute exposure to acrylamide on GABAergic neurons and astrocytes in weaning rat cerebellum. Toxicol Ind Health 2012;28:10-20.

Spencer PS, Schaumburg HH. Nervous system degeneration produced by acrylamide monomer. Environ Health Perspect 1975;11:129-33.

Stett A, Egert U, Guenther E, Hofmann F, Meyer T, Nisch W, et al. Biological application of microelectrode arrays in drug discovery and basic research. Anal Bioanal Chem 2003;377:486-95.

Stiegler NV, Krug AK, Matt F, Leist M. Assessment of chemical-induced impairment of human neurite outgrowth by multiparametric live cell imaging in high-density cultures. Toxicol Sci 2011;121:73-87.

Suzuki K, Pfaff LD. Acrylamide neuropathy in rats. An electron microscopic study of degeneration and regeneration. Acta Neuropathol 1973;24:197-213.

Tamm C, Duckworth J, Hermanson O, Ceccatelli S. High susceptibility of neural stem cells to methylmercury toxicity: effects on cell survival and neuronal differentiation. J Neurochem 2006;97:69-78.

Tareke E, Rydberg P, Karlsson P, Eriksson S, Tornqvist M. Acrylamide: a cooking carcinogen. Chem Res Toxicol 2000;13:517-22.

Tateno M, Ukai W, Ozawa H, Yamamoto M, Toki S, Ikeda H, et al. Ethanol inhibition of neural stem cell differentiation is reduced by neurotrophic factors. Alcohol Clin Exp Res 2004;28 134S-8S

Undie AS, Friedman E. Stimulation of a dopamine D1 receptor enhances inositol phosphates formation in rat brain. J Pharmacol Exp Ther 1990;253:987-92.

van Thriel C, Westerink RH, Beste C, Bale AS, Lein PJ, Leist M. Translating neurobehavioural endpoints of developmental neurotoxicity tests into in vitro assays and readouts. Neurotoxicology 2012;33:911-24.

van Vliet E, Stoppini L, Balestrino M, Eskes C, Griesinger C, Sobanski T, et al. Electrophysiological recording of re-aggregating brain cell cultures on multielectrode arrays to detect acute neurotoxic effects. Neurotoxicology 2007;28:1136-46.

Visan A, Hayess K, Sittner D, Pohl EE, Riebeling C, Slawik B, et al. Neural differentiation of mouse embryonic stem cells as a tool to assess developmental neurotoxicity in vitro. Neurotoxicology 2012;33:1135-46.

Wiedenmann B, Franke WW. Identification and localization of synaptophysin, an integral membrane glycoprotein of $\mathrm{Mr}$ 38,000 characteristic of presynaptic vesicles. Cell 1985:41:1017-28. 
Ying QL, Smith AG. Defined conditions for neural commitment and differentiation. Methods Enzymol 2003;365:327-41.

Zeng X, Chen J, Deng X, Liu Y, Rao MS, Cadet JL, et al. An in vitro model of human dopaminergic neurons derived from embryonic stem cells: MPP+ toxicity and GDNF neuroprotection. Neuropsychopharmacology 2006;31:2708-15.

Zimmer B, Kuegler PB, Baudis B, Genewsky A, Tanavde V, Koh W, et al. Coordinated waves of gene expression during neuronal differentiation of embryonic stem cells as basis for novel approaches to developmental neurotoxicity testing. Cell Death Differ 2011:18:383-95.

Zimmer B, Lee G, Balmer NV, Meganathan K, Sachinidis A, Studer L, et al. Evaluation of developmental toxicants and signaling pathways in a functional test based on the migration of human neural crest cells. Environ Health Perspect 2012;120:1116-22. 